\title{
Pseudomonas spp. and other psychrotrophic microorganisms in inspected and non-inspected Brazilian Minas Frescal cheese: proteolytic, lipolytic and AprX production potential ${ }^{1}$
}

\author{
Pedro I. Teider Junior², José C. Ribeiro Júnior ${ }^{3 *}$ (D), Eric H. Ossugui², \\ Ronaldo Tamanini ${ }^{2}$, Juliane Ribeiro' ${ }^{2}$, Gislaine A. Santos ${ }^{2}$, Amauri A. Alfieri ${ }^{2}$ \\ and Vanerli Beloti ${ }^{2}$
}

\begin{abstract}
Teider Junior P.I., Ribeiro Júnior J.C., Ossugui E.H., Tamanini R., Ribeiro J., Santos G.A., Alfieri A.A. \& Beloti V. 2019. Pseudomonas spp. and other psychrotrophic microorganisms in inspected and non-inspected Brazilian Minas Frescal cheese: proteolytic, lipolytic and AprX production potential. Pesquisa Veterinária Brasileira 39(10):807-815. Instituto Nacional de Ciência e Tecnologia para a Cadeia Produtiva do Leite, Universidade Estadual de Londrina, Rodovia Celso Garcia Cid PR-445 Km 380, Cx. Postal 10.011, Campus Universitário, Londrina, PR 86057-970, Brazil. E-mail: ribeirojuniorjc@gmail.com

The most consumed cheese in Brazil, Minas Frescal cheese (MFC) is highly susceptible to microbial contamination and clandestine production and commercialization can pose a risk to consumer health. The storage of this fresh product under refrigeration, although more appropriate, may favor the growth of spoilage psychrotrophic bacteria. The objective of this study was to quantify and compare Pseudomonas spp. and other psychrotrophic bacteria in inspected and non-inspected MFC samples, evaluate their lipolytic and proteolytic activities and their metalloprotease production potentials. Twenty MFC samples were evaluated: 10 inspected and 10 non-inspected. Counts of psychrotrophic bacteria and Pseudomonas spp., evaluation of the proteolytic and lipolytic potential of the isolates, and identification of potential producers of alkaline metalloprotease (AprX) were assessed. The mean total psychrotrophic counts were $1.07( \pm 2.18) \times 10^{9} \mathrm{CFU} / \mathrm{g}$ in the inspected samples and $4.5( \pm 5.86) \times 10^{8} \mathrm{CFU} / \mathrm{g}$ in the non-inspected, with no significant difference $(\mathrm{p}=0.37)$. The average score of Pseudomonas spp. was $6.86( \pm 18.6) \times 10^{5}$ and $2.08( \pm 3.65) \times 10^{6} \mathrm{CFU} / \mathrm{g}$ for the inspected and non-inspected MFC samples, respectively, with no significant difference $(\mathrm{p}=0.1)$. Pseudomonas spp. represented $0.06 \%$ and $0.004 \%$ of psychrotrophic bacteria found in inspected and non-inspected MFC samples, respectively. Collectively, 694 psychrotrophic strains and 47 Pseudomonas spp. were isolated, of which $59.9 \%$ and $68.1 \%$ were simultaneously proteolytic and lipolytic, respectively. Of the 470 psychrotrophs isolated from inspected and 224 from non-inspected cheese samples, $5.74 \%$ and $2.23 \%$ contained $\operatorname{apr} X$, respectively, while 100 and $86.96 \%$ of the Pseudomonas spp. isolates in inspected and non-inspected cheese samples contained the gene. The production potential of AprX did not, however, determine the proteolytic activity on plates of these isolates under the conditions evaluated in this study. Of total, $65.63 \%$ of the psychrotrophs that contained aprX gene were confirmed as Pseudomonas spp., using genus-specific PCR. Phylogenetic analysis of the 16S rRNA gene of the other psychrotrophs that were potential producers of AprX identified them as Serratia spp. (n=7), Raoultella ornithinolytica $(\mathrm{n}=1)$, and Acinetobacter schindleri $(\mathrm{n}=1)$ in the inspected samples and Psychrobacter sanguinis $(\mathrm{n}=1)$ and Leuconostoc mesenteroides $(\mathrm{n}=1)$ in the non-inspected
\end{abstract}

\footnotetext{
${ }^{1}$ Received on February 18, 2019.

Accepted for publication on April 1, 2019.

${ }^{2}$ Instituto Nacional de Ciência e Tecnologia para a Cadeia Produtiva do Leite (INCT-Cadeia do Leite), Universidade Estadual de Londrina (UEL), Rodovia Celso Garcia Cid PR-445 Km 380, Cx. Postal 10.011, Campus Universitário, Londrina, PR 86057-970, Brazil.
}

\footnotetext{
${ }^{3}$ Escola de Medicina Veterinária e Zootecnia, Universidade Federal do Tocantins (UFT), BR-153 Km 112, Zona Rural, Araguaína, T0 77804-970, Brazil. *Corresponding author: ribeirojuniorjc@gmail.com
} 
samples. The production conditions of Brazilian MFC of these samples, while meeting the legal determinations, are not sufficient to control Pseudomonas and other spoilage-related psychrotrophs. Thus, stricter hygienic measures are required during the formal production of this type of cheese.

INDEX TERMS: Pseudomonas spp., psychrotrophic, microorganisms, Minas Frescal cheese, cheese, AprX production, alkaline metalloprotease, proteolysis, lipolysis.

RESUMO.- [Pseudomonas spp. e outros micro-organismos
psicrotróficos em queijos Minas Frescal inspecionados e não
inspecionados: potencial proteolítico, lipolítico e produção
de AprX.] O mais consumido no Brasil, o queijo Minas Fresca
(QMF) é altamente suscetível à contaminação microbiana e a produção e comercialização clandestina podem representar um risco para a saúde do consumidor. 0 armazenamento deste produto fresco sob refrigeração, embora mais apropriado, pode favorecer a multiplicação de bactérias psicrotróficas deteriorantes. $\mathrm{O}$ objetivo deste estudo foi quantificar e comparar Pseudomonas spp. e outras bactérias psicrotróficas em amostras de QMF inspecionadas e não inspecionadas, avaliar o potencial lipolítico, proteolítico e de produção de metaloprotease alcalina. Vinte amostras de QMF foram avaliadas: 10 inspecionadas e 10 não inspecionadas. Foram avaliadas as contagens de bactérias psicrotróficas e Pseudomonas spp., o potencial proteolítico e lipolítico dos isolados e a identificação de potenciais produtores de metaloprotease alcalina (AprX). A média total das contagens de bactérias psicrotróficas foi de $1,07( \pm 2,18) \times 10^{9} \mathrm{UFC} / \mathrm{g}$ nas amostras inspecionadas e $4,5( \pm 5,86) \times 10^{8} \mathrm{UFC} / \mathrm{g}$ nas não inspecionadas, sem diferença significativa $(\mathrm{p}=0,37)$. A média de Pseudomonas spp. foi de $6,86( \pm 18,6) \times 10^{5}$ e $2,08( \pm 3,65) \times 10^{6} \mathrm{UFC} / \mathrm{g}$ para as amostras QMF inspecionadas e não-inspecionadas, respectivamente, sem diferença significativa $(\mathrm{p}=0,1)$. Pseudomonas spp. representaram $0,06 \%$ e $0,004 \%$ de bactérias psicrotróficas encontradas em amostras QMF inspecionadas e não-inspecionadas, respectivamente. Das amostras inspecionadas e não inspecionadas, foram isoladas 694 colônias psicrotróficas e 47 Pseudomonas spp., dos quais 59,9\% e 68,1\% foram simultaneamente proteolíticos e lipolíticos, respectivamente. Dos 470 isolados de psicrotróficos das amostras de queijo inspecionados e dos 224 isolados das não inspecionadas, 5,74\% e $2,23 \%$ continham o gene $\operatorname{apr} X$, respectivamente, enquanto 100 e 86,96\% das Pseudomonas spp. isoladas em amostras de queijo inspecionadas e não inspecionadas continham o potencial de expressão de AprX. Esse potencial, no entanto, não determinou a atividade proteolítica em placas desses isolados nas condições avaliadas neste estudo. Do total, 65,63\% dos psicrotróficos que continham o gene aprX foram confirmados como Pseudomonas spp., utilizando PCR gênero-específico. A análise filogenética do gene $16 \mathrm{~S}$ rRNA dos outros psicrotróficos que foram produtores potenciais de AprX os identificou como Serratia spp. $(\mathrm{n}=7)$, Raoultella ornithinolytica $(\mathrm{n}=1)$ e Acinetobacter schindleri $(\mathrm{n}=1)$ nas amostras inspecionadas e Psychrobacter sanguinis ( $\mathrm{n}=1)$ e Leuconostoc mesenteroides $(\mathrm{n}=1)$ nas amostras não inspecionadas. As condições de produção do QMF dessas amostras, atendendo às determinações legais, não são suficientes para controlar a Pseudomonas e outros psicrotróficos relacionados à deterioração. Assim, medidas higiênicas mais rígidas são necessárias durante a produção formal deste tipo de queijo.
TERMOS DE INDEXAÇÃO: Pseudomonas spp., micro-organismos, psicrotróficos, queijo, Minas Frescal, produção de AprX, metaloprotease alcalina, proteólise, lipólise.

\section{INTRODUCTION}

By definition, Brazilian Minas Frescal cheese (MFC) is a fresh product obtained by the enzymatic coagulation of milk with rennet and/or other suitable coagulating enzymes, with or without supplementation with specific lactic bacteria, powdered milk, cream, milk solids, sodium chloride, and calcium chloride (Brasil 1997). It is classified as a semi-fat (25 to $44.9 \%$ fat) cheese with very high moisture content (not less than 55.0\%) (Brasil 2004). The production of this type of cheese in Brazil is carried out formally by dairies that follow the legal stipulations of the "Ministério da Agricultura, Pecuária e Abastecimento" (Brasil 1997) and mainly small milk producers, with the objective of adding value and increases the shelf life of milk through the preparation of derivatives.

The MFC is quite susceptible to microbial contamination when prepared using raw milk, or during or after processing (Carvalho et al. 2007). Moreover, it can be a source of food pathogens (Campos et al. 2017).

In addition to pathogenic microorganisms, proteolytic and/or lipolytic microorganisms, mainly psychrotrophs, may interfere with the quality of the MFC, since as it is a fresh product, refrigeration is necessary for its storage. When present in the raw material, psychrotrophic bacteria reduce the industrial yield, flavor, and aroma, being able to render the cheese improper for consumption (Murphy et al. 2016).

As the degradation of proteins results in non-acid metabolites, protease activity confers a bitter taste and putrid smell to the cheese. Undesirable effects are also influenced by the reduction of the integrity of milk proteins, deficient coagulation, and greater loss of casein fragments in the serum, requiring 20-30 percent more milk per kilo of cheese (Samaržija et al. 2012).

Alkaline metalloprotease (AprX), which is heat-resistant, is considered the main microbial protease, and is encoded by $a p r X$. This gene is found in various proteolytic bacteria, such as Pseudomonas spp. and Serratia spp. (Dufour et al. 2008, Marchand et al. 2009, Bagliniere et al. 2013). This enzyme is of great significance to dairy industry, because it leads to the deterioration of casein, which causes significant alterations of the physical and chemical quality and organoleptic properties of raw milk and its derivatives (Dufour et al. 2008).

Milk fat is equally compromised by microbial activity. Microbial lipases elevate heat resistance and promote a rancid flavor and aroma in dairy products. Microbial lipases and proteases remain active even after the elimination of the vegetative forms of micro-organisms by pasteurization (Oliveira et al. 2015, Murphy et al. 2016), as in case of Minas cheese. 
Several studies have demonstrated the predominance of the genus Pseudomonas among dairy psychrotrophs (Ozturkoglu-Budak et al. 2016, Vithanage et al. 2016, Xin et al. 2017). Several species of Pseudomonas are responsible for the deterioration of other refrigerated foodstuffs (Samaržija et al. 2012, Oliveira et al. 2015), since they have the capacity to produce proteolytic and lipolytic enzymes at different temperatures, which reinforces their importance as spoilage agents of the dairy product chain (Scatamburlo et al. 2015, Ribeiro Júnior et al. 2018). Furthermore, because they have a high capacity to form biofilms, allowing them to proliferate in a wide variety of environments (Murphy et al. 2016).

Taking into account the technical problems that spoilage microorganisms cause in dairy products, the objective of this study was to quantify and compare Pseudomonas spp. and other psychrotrophic bacteria in inspected and non-inspected MFC samples, evaluate their lipolytic and proteolytic activities and their metalloprotease production potentials by identification of aprX gene.

\section{MATERIALS AND METHODS}

Sampling and preparation of cheese. Twenty samples of MFC marketed in the municipality of Londrina/PR, from May to June 2017, were evaluated. Ten samples of different brands were collected from supermarkets and were recorded by the Brazilian state or federal inspection system and were thus regarded as formal, inspected. These inspected samples had from 11 to 41 days of manufacture, with 22 days on average.

The remaining 10 MFC samples were collected from different fairs in the municipality and were marketed in a clandestine manner, and were therefore considered non-inspected. It was not possible to determine the period between the manufacture date and the analysis of these non-inspected samples, since the sellers were not necessarily the producers.

The MFC samples evaluated did not present any type of alteration of coloration (white, slightly yellowish), texture (soft) or smell (slightly acidic). They had varying amounts of white or yellowish serum, characteristic of MFC.

The samples were transported under refrigeration to the Laboratory of Inspection of Products of Animal Origin, which is a part of the "Instituto Nacional de Ciência e Tecnologia para a Cadeia Produtiva do Leite" (INCT-Cadeia do Leite) of the "Universidade Estadual de Londrina" (UEL), Paraná, Brazil, where they were immediately processed.

The external surfaces of packaging were sanitized with $70 \%$ alcohol. For the psychrotrophic bacterial count, a 25-g aliquot obtained aseptically from different fragments of the cheese sample was homogenized with $225 \mathrm{~mL}$ of $0.1 \%$ peptone saline in Stomacher blender for 180 seconds, obtaining a $10^{-1}$ dilution. From this dilution, serial decimal dilutions were performed with the same diluent.

For estimating the count of Pseudomonas spp., another 25-g aliquot of each sample was diluted in $225 \mathrm{~mL}$ buffered peptone water (Oxoid ${ }^{\circledR}$, England) and homogenized in a Stomacher blender, according to ISO 11.059 (ISO 2009) recommendations.

Counting of microorganisms. For estimating the psychrotrophic bacterial count, $0.1 \mathrm{~mL}$ of the dilutions were grown in duplicate on the surface of Plate Count Agar (PCA) (Acumedia, Baltimore, USA) plates and incubated at $7^{\circ} \mathrm{C}$ for 10 days.

The count of Pseudomonas spp. was performed according to ISO 11059 (2009). A tenth of $\mathrm{mL}$ of the dilutions was spread on the surface of penicillin pimaricin agar (PPA) plates, prepared with
Pseudomonas agar base (Oxoid) supplemented with 100,000IU/L of penicillin G potassium (Sigma Aldrich ${ }^{\circledR}$, United States), and 0.01g/L of piramicin (Coalhopar F-E-B Biotecnologia ${ }^{\circledR}$, Brazil). The plates were incubated at $25^{\circ} \mathrm{C}$ for $48 \mathrm{~h}$. All colonies were subjected to tests for oxidase and glucose fermentation. Only the oxidase positive, non-glucose fermentative colonies were taken into account for the counts of Pseudomonas spp.

The counts were compared by the t-test using the Statistica v. 6.0 software (StatSoft, OK, USA).

Proteolytic and lipolytic potential of Pseudomonas spp. and others psychrotrophic bacteria. The colonies of Pseudomonas spp. and psychrotrophic bacteria were inoculated onto milk agar plates (Acumedia) supplemented with a solution of $10 \%$ reconstituted milk powder (Molico ${ }^{\circledR}$, Nestlé, São Paulo, Brazil), and in tributyrin agar (HiMedia, Mumbai, India) supplemented with 1\% tributyrin (HiMedia) to assess the proteolytic and lipolytic activity, respectively, according to the procedure stated by Hantsis-Zacharov \& Halpern (2007). The plates were incubated under the same conditions recommended for the bacterial counts.

DNA extraction. The psychrotrophic colonies that showed spoiling potential on plates were grown in brain heart broth $\left(\right.$ Merck $^{\circledR}$, Germany) and incubated at $35^{\circ} \mathrm{C}$ for $48 \mathrm{~h}$, under the same incubation conditions as that for the colonies of Pseudomonas spp. grown in tryptone soy broth (Oxoid). An aliquot of $1 \mathrm{~mL}$ of each broth was used to extract DNA by the simple boiling method, according to the study by Ribeiro Júnior et al. (2016).

Molecular confirmation of Pseudomonas spp. The isolates of Pseudomonas spp. obtained in the counts and the other psychrotrophs were subjected to PCR amplification of a specific region in the $16 \mathrm{~S}$ rRNA gene of the genus Pseudomonas, according to the amplification protocol described by Spilker et al. (2004), using the primers F-GS-PA (GACGGGTGAGTAATGCCTA) and PA-GS-R (CACTGGTGTTCCTTCCTATA). PCR reactions were performed using 50ng of template DNA, $10 \mathrm{nM}$ of each dNTP, $1 \times$ buffer, $75 \mathrm{mmol} / \mathrm{L}$ of $\mathrm{MgCl}_{2}, 20 \mathrm{pmol} / \mathrm{L}$ of each primer, and 2.5U of Platinum Taq DNA polymerase (Invitrogen, CA, USA), to yield a final reaction volume of $50 \mu \mathrm{L}$, recommended by Ribeiro Júnior et al. (2016). Samples which displayed 618-bp amplicons were considered as Pseudomonas spp.

Detection of aprX. PCR of aprX gene (AprX enzyme) was performed using the primers apr I (TAYGGBTTCAAYTCCAAYAC) and apr II (VGCGATSGAMACRTTRCC) and amplification conditions described by Bach et al. (2001). The reaction conditions were the same as those cited above (Ribeiro Júnior et al. 2016), with 194-bp amplicons being considered positive.

Amplification and sequencing of the $16 \mathrm{~S}$ rRNA gene. The isolates that were positive for aprX and were not confirmed as Pseudomonas spp. by genus-specific reaction were subjected to the partial amplification of the 16S rRNA gene using the primers $27 \mathrm{f}$ ( $5^{\prime}$-GAGTTTGATCMTGGCTCAG-3') and 1492r (5'-GGYTACCTTGTTACGACTT-3') (Osborne et al. 2005). The amplification conditions were as follows: 1 cycle of initial denaturation at $94^{\circ} \mathrm{C}$ for $5 \mathrm{~min} ; 35$ cycles at $94^{\circ} \mathrm{C}$ for $1 \mathrm{~min}$, annealing at $58^{\circ} \mathrm{C}$ for $1 \mathrm{~min}$, and primer extension at $72^{\circ} \mathrm{C}$ for $1 \mathrm{~min}$; and a final extension cycle at $72^{\circ} \mathrm{C}$ for $10 \mathrm{~min}$.

The PCR product from the 16S rRNA gene was then purified (PureLink ${ }^{\mathrm{TM}}$ Genomic DNA Purification Kit, Invitrogen) and quantified (Qubit ${ }^{\circledR}$ dsDNA HS Assay Kit, Invitrogen). DNA sequencing was performed by the Sanger method (ABI 3500 Genetic Analyzer, Applied Biosystems, Foster City, USA) in both directions. A representative sequence of each species found was selected for deposit in GenBank.

Phylogenetic analysis for species identification. The quality of the 16S rRNA sequences was evaluated by BioEdit v. 7.2.5 software 
(Hall 1999) and the consensual sequences were generated by CAP 3 (Huang \& Madan 1999). Preliminary identification at the genus level was performed by the BLAST tool of the National Center for Biotechnology Information (NCBI). Once the genera were identified, the sequences were individually aligned by Clustal W with the representative type sequences of all species of the genus available in the Ribosomal Database Project (RDP) ${ }^{4}$; the identification of the species was based on the genetic identity matrix calculated by the Tamura-Nei model in the MEGA software v. 7.0 (Kumar et al. 2016). The phylogenetic trees were elaborated in the same software, using the Neighbor Joining method, Tamura-Nei model, and bootstrap support for 1000 replicates.

\section{RESULTS}

The psychrotroph counts ranged from $3.5 \times 10^{7}-6.85 \times 10^{9} \mathrm{UFC} / \mathrm{g}$ in the inspected cheese samples, with a mean of $1.07( \pm 2.18) \times 10^{9} \mathrm{UFC} / \mathrm{g}$. In the non-inspected cheese samples, psychrotroph counts ranged between $2.6 \times 10^{7}-1.65 \times 10^{9} \mathrm{UFC} / \mathrm{g}$, with a mean of $4.5( \pm 5.86) \times 10^{8} \mathrm{CFU} / \mathrm{g}$. No significant difference was observed between the psychrotroph counts in the inspected and non-inspected cheese samples $(\mathrm{p}=0.37)$.

The mean of Pseudomonas spp. counts was $6.86( \pm 18.6) \times 10^{5}$ and $2.08( \pm 3.65) \times 10^{6} \mathrm{CFU} / \mathrm{g}$ for formally and informally marketed cheese, respectively. There was no significant difference $(\mathrm{p}=0.1)$ between the counts of Pseudomonas spp. among the inspected and non-inspected cheeses, although the average of counts of Pseudomonas spp. in inspected cheese samples was only $32.9 \%$ of that in the non-inspected cheese samples.

\footnotetext{
${ }^{4}$ Ribosomal Database Project(RDP), Center for Microbial Ecology, Michigan State University, Michigan, USA. Available at <https://rdp.cme.msu.edu/ hierarchy>
}

From the plates used for the psychrotroph counts, 694 colonies were isolated: 470 from inspected cheese and 224 from non-inspected cheese. With regards to the isolation of Pseudomonas spp. confirmed by biochemical tests (oxidase positive and glucose negative), 47 isolates were identified, of which 24 were from inspected cheeses and 23 were from non-inspected cheese samples. The spoilage potential of these isolates is described in Table 1.

Of these total number of isolates, 85.9 and $91.5 \%$ of psychrotrophic bacteria and Pseudomonas isolated from the total number of samples of MFC, respectively, showed some type of spoilage potential. Moreover, there was a predominance of proteolytic and lipolytic potential simultaneously in nearly $60 \%$ of psychrotrophic and $70 \%$ of Pseudomonas spp. (Table 1 )

Of the 47 isolates confirmed as Pseudomonas spp. by biochemical tests, 46 (97.9\%) were confirmed by genus-specific PCR.

To verify the potential metalloprotease production capacity, a search of $\operatorname{apr} X$ was conducted individually in all isolates of this study, i.e. 694 psychrotrophic and 46 Pseudomonas spp. isolates proven by genus-specific PCR, totaling 740 reactions, as detailed in Table 2 .

The 32 psychrotrophic isolates that displayed positive results in the assessment of aprX (Table 2) were also subjected to genus-specific PCR for Pseudomonas spp. Of these, 21 (65.63\%) were confirmed, and the other 11 isolates were submitted to partial sequencing of the $16 \mathrm{~S}$ rRNA for identification and phylogenetic analysis.

The identification of these 11 isolates that contained aprX were not identified as Pseudomonas is described in Table 3. Five genera were identified: Serratia spp. $(\mathrm{n}=7)$, Raoultella ornithinolytica $(\mathrm{n}=1)$, Acinetobacter schindleri $(\mathrm{n}=1)$, Psychrobacter sanguinis $(\mathrm{n}=1)$ and Leuconostoc mesenteroides $(n=1)$. The species of the seven strains of Serratia were not identified because high percentages of similarity in the

Table 1. Spoilage potential of isolates of psychrotrophic bacteria, and the genus Pseudomonas isolated from 20 samples of inspected (10) and non-inspected (10) cheeses marketed in the municipality of Londrina, Paraná, from May to June 2017

\begin{tabular}{|c|c|c|c|c|c|c|}
\hline \multirow[t]{2}{*}{ Minas Frescal cheese } & \multirow[t]{2}{*}{ Group } & $\begin{array}{c}\text { Total number of } \\
\text { isolates }\end{array}$ & $\begin{array}{c}\text { Proteolytic and } \\
\text { lipolytic }\end{array}$ & Proteolytic & Lipolytic & Non spoilage \\
\hline & & (n) & $\mathrm{n}(\%)$ & $\mathrm{n}(\%)$ & $\mathrm{n}(\%)$ & $\mathrm{n}(\%)$ \\
\hline \multirow[t]{2}{*}{ Inspected } & Psychrotrophic & 470 & $340(72.4)$ & $63(13.4)$ & $49(10.4)$ & $18(3.8)$ \\
\hline & Pseudomonas spp. & 24 & 17 (70.8) & $4(16.7)$ & $0(0)$ & $3(12.5)$ \\
\hline \multirow[t]{2}{*}{ Non-inspected } & Psychrotrophic & 224 & $76(33.9)$ & 31 (13.9) & $37(16.5)$ & $80(35.7)$ \\
\hline & Pseudomonas spp. & 23 & $15(65.3)$ & $1(4.3)$ & $6(26.1)$ & $1(4.3)$ \\
\hline \multirow[t]{2}{*}{ Total of samples } & Psychrotrophic & 694 & $416(59.9)$ & $94(13.6)$ & $86(12.4)$ & $98(14.1)$ \\
\hline & Pseudomonas spp. & 47 & $32(68.1)$ & $5(10.6)$ & $6(12.8)$ & $4(8.5)$ \\
\hline
\end{tabular}

Table 2. Production potential of metalloprotease ( $a p r X)$ of psychrotrophic bacteria and of the Pseudomonas spp., and the spoilage potential of these isolates from inspected and non-inspected Minas Frescal cheese on agar plates

\begin{tabular}{|c|c|c|c|c|c|c|c|}
\hline \multirow[t]{2}{*}{ Minas Frescal cheese } & \multirow[t]{2}{*}{ Group } & \multirow{2}{*}{$\begin{array}{c}\begin{array}{c}\text { Total number of } \\
\text { isolates }\end{array} \\
(\mathrm{n})\end{array}$} & \multirow{2}{*}{$\begin{array}{c}\text { aprX } \\
\mathrm{n}(\%)\end{array}$} & \multirow{2}{*}{$\begin{array}{c}\text { Proteolytic and } \\
\text { lipolytic }\end{array}$} & \multirow{2}{*}{$\begin{array}{c}\text { Proteolytic } \\
\mathrm{n}(\%)\end{array}$} & \multirow{2}{*}{$\frac{\text { Lipolytic }}{\text { n }(\%)}$} & \multirow{2}{*}{$\begin{array}{c}\text { Non spoilage } \\
\mathrm{n}(\%)\end{array}$} \\
\hline & & & & & & & \\
\hline \multirow[t]{2}{*}{ Inspected } & Psychrotrophic & 470 & $27(5.7)$ & $21(77.78)$ & $2(7.41)$ & $4(14.81)$ & $0(0)$ \\
\hline & Pseudomonas spp. & 23 & $23(100)$ & $16(69.57)$ & $4(17.39)$ & $0(0)$ & $3(13.04)$ \\
\hline \multirow[t]{2}{*}{ Non-inspected } & Psychrotrophic & 224 & $5(2.2)$ & $3(60)$ & $0(0)$ & $2(40)$ & $0(0)$ \\
\hline & Pseudomonas spp. & 23 & $20(86.96)$ & $15(75)$ & $0(0)$ & $4(20)$ & $1(5)$ \\
\hline \multirow[t]{2}{*}{ Total number of samples } & Psychrotrophic & 694 & $32(4.61)$ & $24(75)$ & $2(6.25)$ & $6(18.75)$ & $0(0)$ \\
\hline & Pseudomonas spp. & 46 & $43(93.5)$ & $31(72.10)$ & $4(9.30)$ & $4(9.30)$ & $4(9.30)$ \\
\hline
\end{tabular}


identity matrix (greater than 99\%) were observed within several species of the 17 representative sequences of the genus available in RDP. The possible species indicated by a sequence representative of all isolates in the present study can be observed in Figure 1.

\section{DISCUSSION}

The highest mean score of psychrotrophic in the inspected cheeses compared to non-inspected cheeses can be explained by the greater control in storage, mandatory refrigeration (Brasil 1997), and strict observation in all inspected samples evaluated. Sangaletti et al. (2009) found that the psychrotrophic counts increase in MFC with the refrigeration storage period, increasing from $1.4 \times 10^{3} \mathrm{CFU} / \mathrm{g}$ on the first day after manufacturing to $4.5 \times 10^{11} \mathrm{CFU} / \mathrm{g}$ after 30 days under these conditions. The lack of control or even the absence of refrigeration until the moment of commercialization of non-inspected cheeses can lead to higher counts of mesophilic microorganisms, but result in lower counts of psychrophic bacteria.

As the formally marketed cheese samples already had, on average, 22 days of manufacture, and therefore, were kept under refrigeration, it is possible that the psychrotrophic counts would be lower if the samples were evaluated with a smaller storage period. In addition, the higher psychrotrophic counts in inspected cheese samples can be due to the inoculation of lactic acid bacteria (LAB) cultures in pasteurized milk intended for the production of cheese in dairy products. Several LAB cultures are also psychrotrophic and may demonstrate proteolytic and/or lipolytic activity (Ribeiro Júnior et al. 2018).
Pseudomonas is considered the main genus among psychrotrophic microorganisms in milk and dairy products (Ozturkoglu-Budak et al. 2016, Vithanage et al. 2016, Xin et al. 2017) and contamination can occur by the hands of milkers, and from the surface of the cows' udders and milking equipment, and from poorly sanitized refrigerated tanks (Vidal et al. 2017). From the average counts in the samples evaluated in the present study, however, it is possible to affirm that Pseudomonas spp. represent only 0,06\% of the psychrotrophs $\left(6.86 \times 10^{5}\right.$ of $\left.1.07 \times 10^{9} \mathrm{UFC} / \mathrm{g}\right)$ of the inspected Frescal Minas cheese samples and $0.46 \%\left(2.08 \times 10^{6}\right.$ of $\left.4.5 \times 10^{8} \mathrm{CFU} / \mathrm{g}\right)$ of the non-inspected ones evaluated in the present study. Other psychrotrophs than non-Pseudomonas can be more important for the Brazilian MFC quality and shelf-life, as reported by Ribeiro Júnior et al. (2018) in Brazilian raw milk.

Microorganisms of the Pseudomonas genus in raw milk are eliminated by pasteurization (Dogan \& Boor 2003). Their isolation from inspected cheese samples can be due to recontamination after milk pasteurization, at any stage of production.

It is known that the low efficiency of cleaning and sanitizing of utensils (Gruetzmacher \& Bradley 1999), the capacity of biofilm formation on equipment, temperature, storage time, (Hammad 2015) and the poor quality of water (Cousin \& Bramley 1981, Fagundes et al. 2006) may influence the contamination of processed cheese samples by Pseudomonas spp. in industries. Therefore, additional cleaning and sanitizing measures for equipment should be implemented, which will uphold the quality of pasteurized milk, thus ensuring a better quality of the final product. The presence of Pseudomonas spp. in

Table 3. Genetic Identification and spoilage activity of psychrotrophic bacteria with expression potential of alkaline metalloprotease (aprX) not confirmed as Pseudomonas spp., isolated from inspected and non-inspected Minas Frescal cheese samples

\begin{tabular}{|c|c|c|c|c|c|c|}
\hline Identification & No. & $\begin{array}{c}\text { GenBank accession } \\
\text { No. }\end{array}$ & $\begin{array}{c}\text { Genetic similarity } \\
(\%)\end{array}$ & Cheese sample & $\begin{array}{c}\text { Spoilage potential } \\
\text { (No.) }\end{array}$ & Affiliation \\
\hline Serratia spp. & 7 & MG932677 & $99.2-99.8$ & Inspected & $\begin{array}{c}\text { Prot and Lipo (6) } \\
\text { Prot (1) }\end{array}$ & Gammaproteobacteria \\
\hline Raoultella ornithinolytica & 1 & MG932678 & 100 & Inspected & Prot and Lipo & Gammaproteobacteria \\
\hline Acinetobacter schindleri & 1 & MG932679 & 99.6 & Inspected & Lipo & Gammaproteobacteria \\
\hline Psychrobacter sanguinis & 1 & MG932680 & 99.8 & Non-inspected & Lipo & Gammaproteobacteria \\
\hline Leuconostoc mesenteroides & 1 & MG932681 & 100 & Non-inspected & Lipo & Firmicutes \\
\hline
\end{tabular}

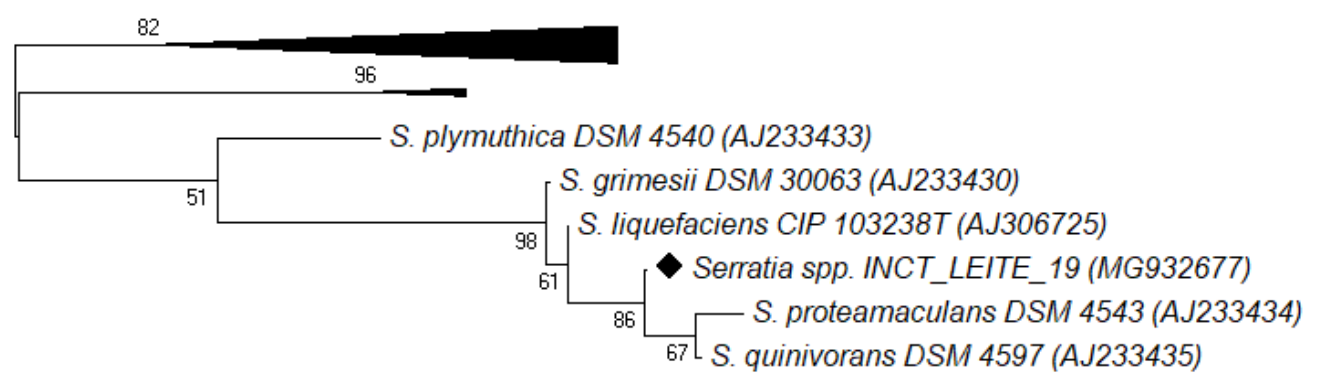

0.005

Fig.1. Phylogenetic tree of species of the genus Serratia (GenBank accession number) prepared using the alignment of $668 \mathrm{bp}$ of the $16 \mathrm{~S}$ rRNA gene, Neighbor Joining method, Tamura-Nei model, and bootstrap support for 1000 replicates. The strain marked with a diamond symbol is representative of seven species of this genus isolated in this study. The bar indicates the percentage of nucleotide substitution. 
non-inspected cheeses can be due to possible manufacturing with raw milk or environmental contamination at any point in the processing or marketing of the cheese.

A study by Sangaletti et al. (2009) demonstrated that $96.38 \%$ of psychrotrophic bacteria isolated from MFC showed lipolytic potential, and $78.17 \%$ showed proteolytic potential, which is as high as the value in the present study (Table 1).

Dogan \& Boor (2003) isolated 338 strains of Pseudomonas spp. from raw milk and found that $51 \%$ were producers of proteases and $67 \%$ were producers of lipase, suggesting that the lipolytic and proteolytic activities varied among the different species of Pseudomonas spp. In these study the Pseudomonas are identify only at genus level. In the study by Hammad (2015), of 80 Domiati cheese samples collected, 70 were positive for Pseudomonas spp. Of the 80 isolates confirmed as Pseudomonas, $97.5 \%$ and $87.5 \%$ were potentially proteolytic and lipolytic, respectively. $P$. fluorescens was the most common species isolated.

The results of AprX production by Pseudomonas spp. in this study were higher than that in the study of Hammad (2015), who reported that 33 (41.25\%) isolates of Pseudomonas spp. from cheeses were aprX positive.

It can be verified that not all the isolates that exhibit aprX express it constantly, since isolates that showed the aprX gene did not present proteolytic activity in plaques (Table 2). This intermittence in the expression of aprX may be conditioned by other factors, such as the availability of other substrates in the medium, as was also observed in another study (Ribeiro Júnior et al. 2018).

Serratia spp. are known psychrotrophs with a potential expression of AprX (Ribeiro Júnior et al. 2018). The present study identified all the isolates of this genus in samples of formally produced MFC (Table 3). This bacterium, as well as all other gram-negative bacteria, is not thermoduric bacteria. Thus, it is possible to affirm that the contamination of cheeses by these micro-organisms occurred after pasteurization, i.e., during processing.

Despite displaying an expression potential of AprX, Acinetobacter schindleri, Psychrobacter sanguinis, and Leuconostoc mesenteroides showed no proteolytic activity on the plates, but only a lipolytic activity (Table 3). Thus, like strains of Pseudomonas spp., the expression of $\operatorname{apr} X$ may be related to other unknown factors.

The genus Raoultella was separated from the genus Klebsiella in 2001 (Drancourt et al. 2001). This is a known human pathogen (Seng et al. 2016) and presents only four type sequences available in the RDP. In Figure 2, it is possible to observe that the isolate of the present study was grouped with the species Raoultella ornithinolytica and was also $100 \%$ compatible with this species in the identification by the identity matrix (Table 2). No previous reports of the production potential of AprX were found, but there is a description of a psychotrophic proteolytic agent of milk in Slovakia (Pukančíková et al. 2016).

The genus Acinetobacter is a known component of spoilage-related microbiota of milk (Von Neubeck et al. 2015). These bacteria are psychrotrophs (Vithanage etal. 2016, Xin et al. 2017) and considered as emerging pathogens associated with human infections (Turton et al. 2010). The large percentage of identity matrix similarity (Table 3) observed in the strain isolated in this study with the species A. schindleri strain type LUH5232T (accession number AJ278311) can also be found in the phylogenetic proximity of the strains in Figure 3. No previous reports on the potential of AprX expression in Acinetobacter species or the isolation of $A$. schindleri species from cheeses were found.

P. sanguinis isolated in this study is reported to be an uncommon human pathogen (Le Guern et al. 2014) with a preference for cold (Rodrigues et al. 2009) and aquatic environments (Wirth et al. 2012). No previous reports of the isolation of this species in milk or cheeses, or their spoilage potential, were found. Delbès et al. (2007) found only the species P. faecalis in raw milk and cheeses in France. In Figure 4, one can observe the phylogenetic proximity of the strain isolated by the present work with the P. sanguinis type strain, with a similarity calculated at $99.8 \%$.

Bacteria of the genus Leuconostoc are described as lactic acid bacteria (LAB) (Kleppen et al. 2012). Figure 5 indicates that the isolate from this study presents $100 \%$ of phylogenetic proximity with the type species L. mesenteroides (AB023247). This isolate was obtained from a sample of non-inspected cheese. Therefore, the possibility that this strain originates from some LAB culture used as a fermenting agent in cheese production is discarded, or rather, it is a component of the autochthonous milk microbiota. The expression potential of AprX by this strain is also relevant, since this enzyme is related to the Gammaproteobacteria class, according to Table 3.

A study by Ribeiro Júnior et al. (2018) also demonstrated that other psychrotrophic microorganisms from milk, besides Pseudomonas spp., may present a potential expression of AprX,

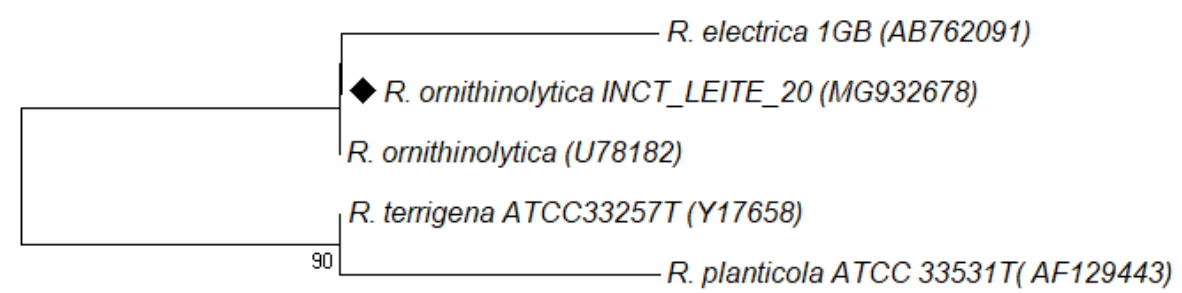

Fig.2. Phylogenetic tree of type sequences of species of the genus Raoultella (GenBank accession number) prepared using the alignment of $384 \mathrm{bp}$ of the $16 \mathrm{~S}$ rRNA gene, Neighbor Joining method, Tamura-Nei model, and bootstrap support for 1000 replicates. The strain marked with a diamond symbol was isolated in this study. The bar indicates the percentage of nucleotide substitution. 


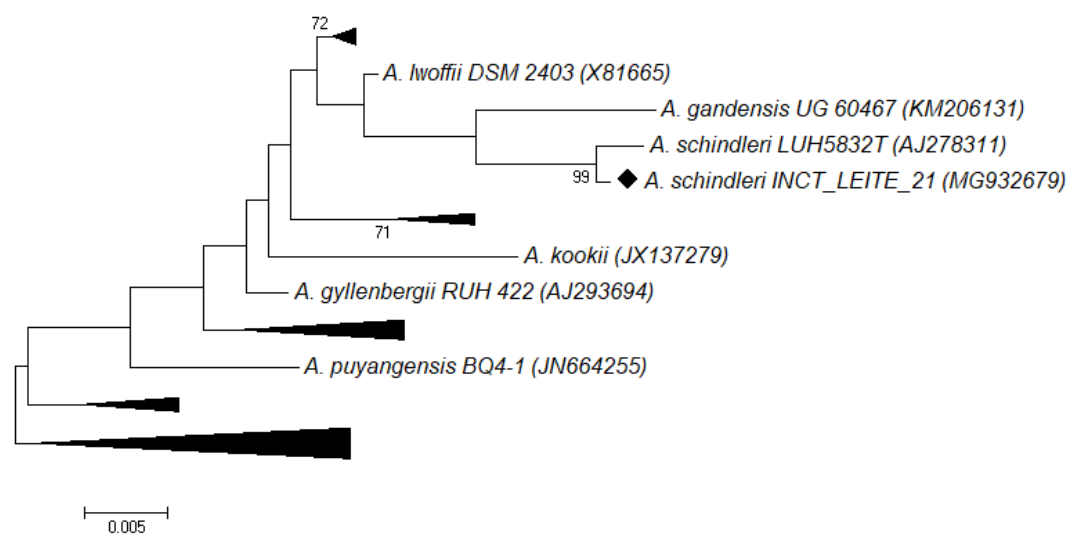

Fig.3. Phylogenetic tree of type sequences of species of the genus Acinetobacter (GenBank accession number) prepared using the alignment of $541 \mathrm{bp}$ of the $16 \mathrm{~S}$ rRNA gene, Neighbor Joining method, Tamura-Nei model, and bootstrap support for 1000 replicates. The strain marked with a diamond symbol was isolated in this study. The bar indicates the percentage of nucleotide substitution.

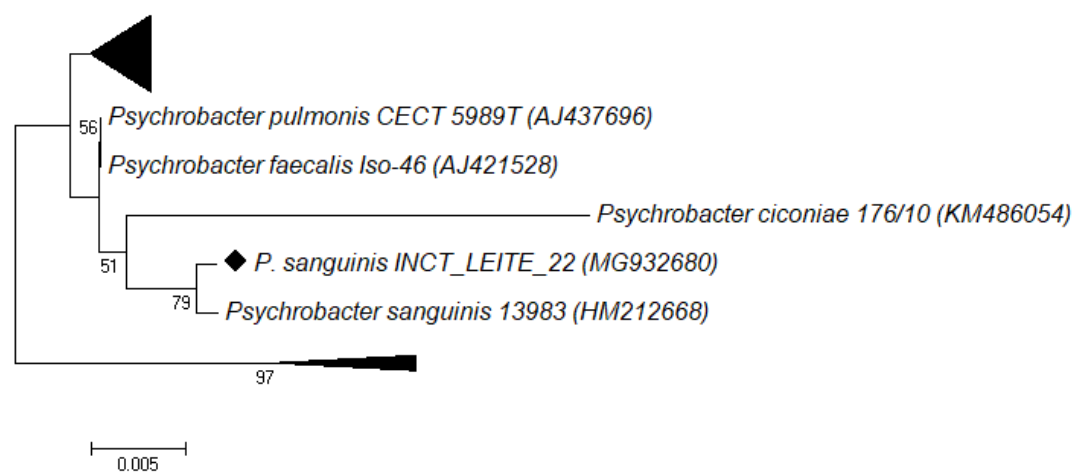

Fig.4. Phylogenetic tree of sequences of type species of the genus Psychrobacter accession (GenBank accession number) prepared using the alignment of 468bp of the 16S rRNA gene, Neighbor Joining method, Tamura-Nei model, and bootstrap support for 1000 replicates. The CEPA marked with diamond symbol was isolated in this study. The bar indicates the percentage of nucleotide substitution.

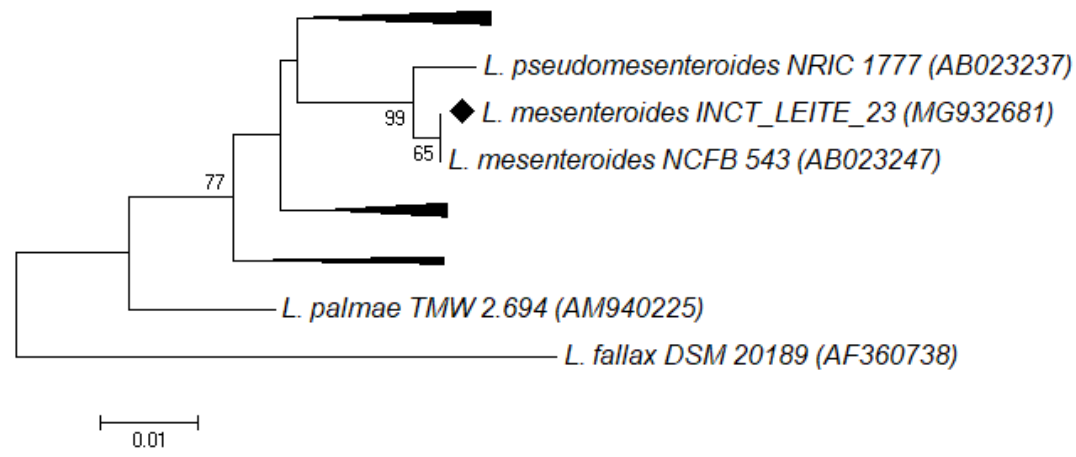

Fig.5. Phylogenetic tree of sequences of type species of the genus Leuconostoc (GenBank accession number) prepared using the alignment of 323bp of the $16 \mathrm{~S}$ rRNA gene, Neighbor Joining method, Tamura-Nei model, and bootstrap support for 1000 replicates. The strain marked with a diamond symbol was isolated in this study. The bar indicates the percentage of nucleotide substitution.

such as Serratia ureilytica, Enterobacter kobei and Yersinia enterocolitica, all belonging to the Gammaproteobacteria class, in addition to $R$. ornithinolytica, $A$. schindleri and $P$. sanguinis identified in this study (Table 3). However, the isolation of L. mesenteroides (Bacilli) reveals that the dispersion of aprX can go beyond the Gammaproteobacteria class, broadening the spectrum of spoilage-related microorganisms of milk and dairy products.

\section{CONCLUSIONS}

Pseudomonas spp. and other potential spoilage-related psychrotrophs can be isolated in equivalent quantities, both in formally produced and commercialized and non-inspected MFC in Brazil.

The industrial production processes are not sufficient to control the contamination of MFC by these microorganisms, since the cheese possibly manufactured from raw milk present 
lower counts of spoilage-related psychrotrophs than that industrially processed with pasteurized milk. Or, it is possible that the lack of refrigeration of the informal cheese was determinant of the low count of psychrotrophs in relation to the formal MFC.

Pseudomonas and other psychrotrophs isolated from MFC are, in their majority, simultaneously proteolytic and lipolytic, and may deteriorate the quality of the cheeses. Furthermore, microorganisms not yet described as cheese-spoilage bacteria may be emerging targets for quality control, and the factors that influence the expression and the dispersion of $a p r X$ gene between genera of psychrotrophs need to be elucidated.

The production of MFC with pasteurized milk should be safeguarded to avoid the risk to consumer health. In addition, industrial hygiene practices should be followed to ensure cheese production with less contamination by spoilage microorganisms.

Acknowledgements.- This study was supported by the following Brazilian institutes: National Council of Scientific and Technological Development (CNPq, grant number 305062/2015-8, Brasília, Brazil), Brazilian Federal Agency for Support and Evaluation of Graduate Education (CAPES, process 88887.145705/2017-00, Brasília, Brazil), Financing of Studies and Projects (FINEP, Brasília, Brazil), and the Araucaria Foundation (FAP-PR, Curitiba, Paraná, Brazil). The authors are grateful for the collaboration of the researcher Elis Lorenzetti for support in molecular biology.

Conflict of interest statement.- The authors declare that they have no conflicts of interest.

\section{REFERENCES}

Bach H.J., Hartmann A., Schloter M. \& Munch J.C. 2001. PCR primers and functional probes for amplification and detection of bacterial genes for extracellular peptidases in single strains and in soil. J. Microbiol. Methods 44(2):173-182. <http://dx.doi.org/10.1016/S0167-7012(00)00239-6> $<$ PMid:11165346>

Bagliniere F., Mateos A., Tanguy G., Jardin J., Briard-Bion V., Rousseau F., Robert B., Beaucher E., Gaillard J.L., Amiel C., Humbert G., Dary A. \& Gaucheron F. 2013. Proteolysis of ultra-high temperature- treated casein micelles by AprX enzyme from Pseudomonas fluorescens induces their destabilisation. Int. Dairy J. 31(2):55-61. <http://dx.doi.org/10.1016/j.idairyj.2013.02.011>

Brasil 1997. Regulamento Técnico Para Fixação de Identidade e Qualidade do Queijo Minas Frescal. Portaria no 352, de 04 de setembro de 1997, Diário Oficial da União, Ministério da Agricultura, Pecuária e Abastecimento, Brasília, DF.

Brasil 2004. Regulamento Técnico para Fixação de Identidade e Qualidade do Queijo Minas Frescal. Instrução Normativa no 4, de 1 de março de 2004, Diário Oficial da União, Ministério da Agricultura, Pecuária e Abastecimento, Brasília, DF.

Campos A.C.L.P., Puño-Sarmiento J.J., Medeiros L.P., Gazal L.E.S., Maluta R.P., Navarro A., Kobayashi R.K.T., Fagan E.P. \& Nakazato G. 2017. Virulence genes and antimicrobial resistance in Escherichia coli from cheese made from unpasteurized milk in Brazil. Foodborne Pathog Dis. 15(2):94-110. <http://dx.doi.org/10.1089/fpd.2017.2345><PMid:29215297>

Carvalho J.D.G., Viotto W.H. \& Kuaye A.Y. 2007. The quality of Minas Frescal cheese produced by different technological processes. Food Control 18(3):262-267. <http://dx.doi.org/10.1016/j.foodcont.2005.10.005>

Cousin M.A. \& Bramley A.J. 1981. The microbiology of raw milk, p.119-163. In: Robinson R.K. (Ed.), Dairy Microbiology of Milk. Applied Science Publishers, London.
Delbès C., Ali-Mandjee L. \& Montel M.C. 2007. Monitoring bacterial communities in raw milk and cheese by culture-dependent and -independent $16 \mathrm{~s}$ rrna gene-based analyses. Appl. Environ. Microbiol. 73(6):1882-1891.<http:// dx.doi.org/10.1128/AEM.01716-06><PMid:17259356>

Dogan B. \& Boor K.J. 2003. Genetic diversity and spoilage potentials among Pseudomonas spp. isolated from fluid milk products and dairy processing plants. Appl. Environ. Microbiol. 69(1):130-138. <http://dx.doi.org/10.1128/ AEM.69.1.130-138.2003><PMid:12513987>

Drancourt M., Bollet C., Carta A. \& Rousselier P. 2001. Phylogenetic analyses of Klebsiella species delineate Klebsiella and Raoultella gen. nov., with description of Raoultella ornithinolytica comb. nov., Raoultella terrigena comb. nov. and Raoultella planticola comb. nov. Int. J. Syst. Evol. Microbiol. 51(Pt 3):925-932. <http://dx.doi.org/10.1099/00207713-51-3-925> $<$ PMid:11411716>

Dufour D., Nicodeme M., Perrin C., Driou A., Brusseaux E., Humbert G., Gaillard J.L. \& Dary A. 2008. Molecular typing of industrial strains of Pseudomonas spp. isolated from milk and genetical and biochemical characterization of an extracellular protease produced by one of them. Int. J. Food Microbiol. 125(2):188-196. <http://dx.doi.org/10.1016/j.ijfoodmicro.2008.04.004> $<$ PMid:18511140>

Fagundes C.M., Fischer V., Silva W.P., Carbonera N. \& Araújo M.R. 2006. Presence of Pseudomonas spp. in milking phases with different hygienic handling procedures and in refrigerated milk. Ciência Rural 36(2):568-572. <http://dx.doi.org/10.1590/S0103-84782006000200032>

Gruetzmacher T.J. \& Bradley Junior R.L. 1999. Identification and control of processing variables that affect the quality and safety of fluid milk. J. Food Protect. 62(6):625-631. <http://dx.doi.org/10.4315/0362-028X-62.6.625> <PMid:10382651>

Hall T.A. 1999. BioEdit: a user-friendly biological sequence alignment editor and analysis program for Windows 95/98/NT. Nucleic Acids Symp. Ser. 41:95-98.

Hammad A.M. 2015. Spoilage potential of Pseudomonas spp. isolated from domiati cheese. Assiut Vet. Med. J. 61(147):18-23.

Hantsis-Zacharov E. \& Halpern M. 2007. Culturable psychrotrophic bacterial communities in raw milk and their proteolytic and lipolytic traits. Appl. Environ. Microbiol. 73(22):7162-7168. <http://dx.doi.org/10.1128/ AEM.00866-07><PMid:17890340>

Huang X. \& Madan A. 1999. CAP3: a DNA sequence assembly program. Genome Res. 9(9):868-877. <http://dx.doi.org/10.1101/gr.9.9.868> <PMid:10508846>

ISO 2009. ISO 11.059, Milk and Milk Products: method for the enumeration of Pseudomonas spp. ISO/TS 11059:2009 (IDF/RM 225:2009), International Organization for Standardization, Geneva, Switzerland.

Kleppen H.P., Nes I.F. \& Holo H. 2012. Characterization of a Leuconostoc bacteriophage infecting flavor producers of cheese starter cultures. Appl. Environ. Microbiol. 78(18):6769-6772. <http://dx.doi.org/10.1128/ AEM.00562-12><PMid:22798359>

Kumar S., Stecher G. \& Tamura K. 2016. MEGA7: molecular evolutionary genetics analysis version 7.0 for bigger datasets. Mol. Biol. Evol. 33(7):18701874. <http://dx.doi.org/10.1093/molbev/msw054><PMid:27004904>

Le Guern R., Wallet F., Vega E., Courcol R.J. \& Loïez C. 2014. Psychrobacter sanguinis: an unusual bacteria for a nosocomial meningitis. J. Clin. Microbiol. 52(9):3475-3477. <http://dx.doi.org/10.1128/JCM.01197-14> <PMid:24989605>

Marchand S., Vandriesche G., Coorevits A., Coudijzer K., De Jonghe V., Dewettinck K., De Vos P., Devreese B., Heyndrickx M. \& De Block J. 2009. Heterogeneity of heat-resistant proteases from milk Pseudomonas species. Int. J. Food Microbiol. 133(1/2):68-77. <http://dx.doi.org/10.1016/j. ijfoodmicro.2009.04.027><PMid:19481283>

Murphy S.C., Martin N.H., Barbano D.M. \& Wiedmann M. 2016. Influence of raw milk quality on processed dairy products: How do raw milk quality 
test results relate to product quality and yield? J. Dairy Sci. $99(12): 10128-$ 10149. <http://dx.doi.org/10.3168/jds.2016-11172><PMid:27665134>

Oliveira G.B., Favarin L., Luchese R.H. \& McIntosh D. 2015. Psychrotrophic bacteria in milk: how much do we really know? Braz. J. Microbiol. 46(2):313-321.<http://dx.doi.org/10.1590/S1517-838246220130963> $<$ PMid:26273245>

Osborne C.A., Galic M., Sangwan P. \& Janssen P.H. 2005. PCRgenerated artefact from 16S rRNA gene-specific primers. FEMS Microbiol. Lett. 248(2):183187. <http://dx.doi.org/10.1016/j.femsle.2005.05.043><PMid:15961258>

Ozturkoglu-Budak S., Wiebenga A., Bron P.A. \& de Vries R.P. 2016. Protease and lipase activities of fungal and bacterial strains derived from an artisanal raw ewe's milk cheese. Int. J. Food Microbiol. 237:17-27. <http://dx.doi. org/10.1016/j.ijfoodmicro.2016.08.007><PMid:27541978>

Pukančíková L., Lipničanová S., Kačániová M., Chmelová D. \& Ondrejovič M. 2016. Natural microflora of raw cow milk and their enzymatic spoilage potential. Nova Biotechnologica Chimica 15(2):142-155. <http://dx.doi. org/10.1515/nbec-2016-0015>

Ribeiro Júnior J.C., Tamanini R., Soares B.F., Oliveira A.M., Silva F.G., Silva F.F., Augusto N.A. \& Beloti V. 2016. Efficiency of boiling and four other methods for genomic DNA extraction of deteriorating spore-forming bacteria from milk. Semina, Ciênc. Agrarárias 37:3069-3078.

Ribeiro Júnior J.C., Oliveira A.M., Silva F.G., Tamanini R., Oliveira A.L.M. \& Beloti V. 2018. The main spoilage related psychrotrophic bacteria in refrigerated raw milk. J. Dairy Sci. 101(1):75-83. <http://dx.doi.org/10.3168/jds.201713069> <PMid:29102138>

Rodrigues D.F., Jesus E.C., Ayala-Del-Río H.L., Pellizari V.H., Gilichinsky D., Sepulveda-Torres L. \& Tiedje J.M. 2009. Biogeography of two cold-adapted genera: Psychrobacter and Exiguobacterium. ISME J. 3(6):658-665. <http:// dx.doi.org/10.1038/ismej.2009.25 > <PMid:19322243>

Samaržija D., Zamberlin Š. \& Pogačić T. 2012. Psychrotrophic bacteria and milk and dairy products quality. Mljekarstvo. Dairy 62(2):77-95.

Sangaletti N., Porto E., Brazaca S.G.C., Yagasaki C.A., Dalla Dea R.C. \& Silva M.V. 2009. Shelf-life of Minas Frescal cheese. Ciênc. Tecnol. Aliment. 29(2):262269. <http://dx.doi.org/10.1590/S0101-20612009000200004>

Scatamburlo T.M., Yamazi A.K., Cavicchioli V.Q., Pieri F.A. \& Nero L.A. 2015. Spoilage potential of Pseudomonas species isolated from goat milk. J. Dairy Sci. 98(2):759-764. <http://dx.doi.org/10.3168/jds.2014-8747> <PMid:25497792>
Seng P., Boushab B.M., Romain F., Gouriet F., Bruder N., Martin C., Paganelli F., Bernit E., Treut Y.P.L., Thomas P., Papazian L., Raoult D. \& Stein A. 2016. Emerging role of Raoultella ornithinolytica in human infections: a series of cases and review of the literature. Int. J. Infect. Dis. 45:65-71. <http:// dx.doi.org/10.1016/j.ijid.2016.02.014><PMid:26921549>

Spilker T., Coenye T., Vandamme P. \& Lipuma J.J. 2004. PCR-based assay for differentiation of Pseudomonas aeruginosa from other Pseudomonas species recovered from cystic fibrosis patients. J. Clin. Microbiol. 42(5):2074-2079. <http://dx.doi.org/10.1128/JCM.42.5.2074-2079.2004><PMid:15131172>

Turton J.F., Shah J., Ozongwu C. \& Pike R. 2010. Incidence of Acinetobacter species other than A. baumannii among clinical isolates of Acinetobacter: evidence for emerging species. J. Clin. Microbiol. 48(4):1445-1449. <http:// dx.doi.org/10.1128/JCM.02467-09><PMid:20181894>

Vidal A.M.C., Saran Netto A., Vaz A.C.N., Capodifóglio E., Gonçalves A.C.S., Rossi G.A.M., Figueiredo A.S. \& Ruiz V.L.A. 2017. Pseudomonas spp.: contamination sources in bulk tanks of dairy farms. Pesq. Vet. Bras. 37(9):941-948. <http:// dx.doi.org/10.1590/s0100-736x2017000900008>

Vithanage N.R., Dissanayake M., Bolge G., Palombo E.A., Yeager T.R. \& Datta N. 2016. Biodiversity of culturable psychrotrophic microbiota in raw milk attributable to refrigeration conditions, seasonality and their spoilage potential. Int. Dairy J. 57:80-90. <http://dx.doi.org/10.1016/j. idairyj.2016.02.042>

Von Neubeck M., Baur C., Krewinkel M., Stoeckel M., Kranz B., Stressler T., Fischer L., Hinrichs J., Scherer S. \& Wenning M. 2015. Biodiversity of refrigerated raw milk microbiota and their enzymatic spoilage potential. Int. J. Food Microbiol. 211:57-65. <http://dx.doi.org/10.1016/j. ijfoodmicro.2015.07.001><PMid:26173200>

Wirth S.E., Ayala-Del-Río H.L., Cole J.A., Kohlerschmidt D.J., Musser K.A., Sepúlveda-Torres L.C., Thompson L.M. \& Wolfgang W.J. 2012. Psychrobacter sanguinis sp. nov., recovered from four clinical specimens over a 4-year period. Int. J. Syst. Evol. Microbiol. 62(Pt 1):49-54. <http://dx.doi.org/10.1099/ ijs.0.029058-0 > <Mid:21317274>

Xin L., Meng Z., Zhang L., Cui Y., Han X. \& Yi H. 2017. The diversity and proteolytic properties of psychrotrophic bacteria in raw cows' milk from North China. Int. Dairy J. 66:34-41. <http://dx.doi.org/10.1016/j.idairyj.2016.10.014> 